\title{
Rezime
}

Banke su u svetu pre trideset godina poslovale samo na nacionalnom nivou. $U$ to vreme započet proces globalizacije prouzrokovao je da banke počnu da posluju i na međunarodnom planu. Za zemlje Zapadnog Balkana transformacija bankarskih sistema na tržišne uslove poslovanja tokom devedesetih godina prošlog veka i početkom ovog veka predstavljala je veliku promenu. Sam proces transformacije državnih banaka sprovođen je uglavnom prodajom banaka inostranim investitorima. Navedeni proces doneo je niz prednosti kao što je poboljšanje konkurencije i uvođenje novih tehnoogija u navedenim zemljama. Finansijska kriza koja je pogodila zemlje Zapadnog Balkana u 2008. godini uticala je na poslovanje banaka u tim zemljama. Period posle krize naglasio je dodatno potrebu harmonizacije regulacije poslovanja banaka u Evropi, pri čemu je Jedinstveni mehanizam supervizije, koji je počeo da funkcioniše 2014. godine, početni korak ka formiranju Evropske bankarske unije, a sporazum Basel III zakonski okvir za regulisanje poslovanja evropskih banaka.

Ključne reči: liberalizacija, globalizacija, transformacija banaka, balkanske zemlje, finansijska kriza, supervizija 


\section{TRANSFORMATION OF THE BANKING SYSTEMS IN THE WESTERN BALKANS}

Dušan Mešić

National Bank of Serbia dusan.mesic@nbs.rs
Translation provided by the author

\section{Summary}

Thirty years ago, the banks worldwide were doing business only at the national level. The globalization process which started at that time caused the banks to launch their operations at the international level, as well. For the countries of the Western Balkans the transformation of their respective banking systems to a market economy during the 1990's and at the beginning of this century was a great change. The transformation process of state-owned banks itself was mostly conducted by sale of banks to foreign investors. The above-mentioned process brought a host of advantages, such as an improvement of competition and the introduction of new technologies in those countries. The financial crisis that hit the Western Balkans in 2008 exerted an influence on banking operations in these countries. The post-crisis period additionally highlighted the need to harmonize the banking regulation in Europe, with the Single Supervisory Mechanism, which started functioning in 2014, being the initial step towards the formation of the European Banking Union, and the Basel III Accord towards regulating the operations of European banks.

Keywords: liberalization, globalization, transformation of banks, Balkan countries, financial crisis, supervision 


\section{Uvod}

Rad analizira transformaciju bankarskih sistema zemalja Zapadnog Balkana u procesu privatizacije državnih banaka $u$ privatne $i$ ulogu stranih investitora $\mathrm{u}$ tom procesu. $\mathrm{U}$ analizi Zapadni Balkan uključuje Rumuniju, Bugarsku, Crnu Goru, BiH, Makedoniju i Srbiju. Transformacija bankarskog sistema neke zemlje znači privatizaciju banaka kao i prelazak poslovanja banaka sa netržišnih na tržišne uslove što uključuje i pridržavanje prudencione regulative u poslovanju. Strane banke su banke koje posluju u zemljama Zapadnog Balkana i čiji su osnivači strana pravna lica. Domaće banke su banke koje posluju u zemljama Zapadnog Balkana čiji su osnivači ili država, u kom slučaju govorimo o domaćim državnim bankama, ili domaća privatna lica, u kom slučaju govorimo o domaćim privatnim bankama. Osim banaka, u zemljama Zapadnog Balkana prisutna su i predstavništva stranih banaka i njihove filijale. Predstavništvo strane banke je organizacioni deo strane banke $u$ zemljama Zapadnog Balkana, bez statusa pravnog lica, koji ne može obavljati poslove koje može obavljati banka, već isključivo poslove istraživanja tržišta. Filijala je organizacioni deo strane banke u zemljama Zapadnog Balkana, bez statusa pravnog lica, koji obavlja poslove koje može obavljati banka u skladu sa zakonom koji reguliše poslovanje banaka u određenoj zemlji.

Bankarski sistemi širom sveta tokom devedesetih godina prošlog veka suštinski su promenjeni. Na početku ovog perioda većina razvijenih zemalja je privatizovala državne banke. Ovaj proces se odigravao uporedo sa procesom privatizacije telekomunikacionih kompanija, železničkog i avio saobraćaja. To je bila posledica deregulacije finansijskih usluga, tehnoloških inovacija i otvaranja bankarskih sistema država međunarodnoj konkurenciji. Banke u zemljama Zapadnog Balkana bile su zaštićene u odnosu na stranu konkurenciju dugi niz godina. Nastanak globalnog tržišta, tehnološke inovacije kao i bankarske krize u pojedinim zemljama koje su se tada desile primorale su banke da promene način na koji posluju, a deregulacija poslovanja banaka na nacionalnom nivou omogućila je ulazak stranih banaka na domaće tržište. Kao rezultat ovih procesa, nestale su razlike između banaka i nebankarskih finansijskih institucija, kao i područja u kojima posluju finansijske institucije.

Kada su zemlje Zapadnog Balkana postigle društveni konsenzus o neophodnosti privatizacije bankarskih sistema, usledile su aktivnosti koje su uticale na efekte privatizacije, što uključuje donošenje odluke $u$ pogledu načina sprovođenja procesa, da li putem interne ili eksterne privatizacije, uloge stranog kapitala, da li izabrati strateškog partnera između svetskih bankarskih i finansijskih grupa, što podrazumeva dominantnog budućeg vlasnika ili zagovarati pristup diversifikovane vlasničke strukture.

U finansijskoj teoriji efikasnost primene načina privatizacije razmatrana je $\mathrm{u}$ brojnim studijama. Fridman (Frydman i saradnici, 1999) u svojim istraživanjima vrši poređenja efikasnosti internih i eksternih načina privatizacije. On zaključuje da interna privatizacija, podelom akcija zaposlenima, ne dovodi do poboljšanja performansi privatizovanih banaka (lbid, str. 1.154).

Istraživanje koje je analiziralo uticaj privatizacije na efikasnost bankarskog sistema neke zemlje sproveo je Buh (Buch, 1997) i ono je ukazalo da vlasnička struktura bankarskog sistema ima bitnu ulogu pri analizi efikasnosti. Prema rezultatima ovog istraživanja, kao posledica privatizacije, strane banke su poslovale uspešnije u poređenju sa državnim bankama u zemljama Zapadnog Balkana.

Deregulacija i globalizacija finansijskih usluga dovele su do dramatičnih promena $u$ učešću stranih banaka u bankarskim sistemima Zapadnog Balkana krajem prošlog veka, a naročito u prvoj dekadi ovog veka. Tako je uporedo sa smanjenjem učešća državnih banaka u ukupnom broju banaka prisutno značajno povećanje broja stranih banaka u zemljama Zapadnog Balkana, uz manje promene broja domaćih privatnih banaka.

\section{Periodi u razvoju bankarskih sistema zemalja Zapadnog Balkana}

Bankarska tržišta zemalja Zapadnog Balkana u poređenju sa bankarskim tržištem Evropske unije nedovoljno su razvijena i mala (Barjaktarović i Paunović, 2012, str. 85). Banke su tokom devedesetih godina prošlog veka 


\section{Introduction}

The paper analyzes the transformation of the banking systems in the Western Balkans in the process of privatization of state-owned banks into private and the role of foreign investors in that process. In the analysis, the Western Balkans encompass Romania, Bulgaria, Montenegro, Bosnia and Herzegovina, Macedonia and Serbia. The transformation of the banking system of a certain country means the privatization of banks as well as the transition of banking operations from nonmarket to market conditions, which includes compliance with prudential regulation while conducting their business operations. Foreign banks are banks that operate in the Western Balkans and whose founders are foreign legal entities. Domestic banks are banks that operate in the Western Balkans, whose founders are either the state, domestic state-owned banks, or domestic private entities, domestic private banks. Besides banks, in the countries of the Western Balkans representative offices of foreign banks and their branches are also present. The representative office of a foreign bank is an organizational part of a foreign bank in the countries of the Western Balkans, without the status of a legal entity, which cannot perform banking operations, but exclusively deals with market research. The branch is an organizational part of a foreign bank operating in the countries of the Western Balkans, without the status of a legal entity, which is permitted to conduct banking operations in accordance with the legislation which regulates banking operations in a certain country.

Banking systems around the world were fundamentally changed during the 1990s. At the beginning of this period most developed countries privatized the state-owned banks. This process was concurrent with the privatization process of telecommunication operators, railway and air transport. This was the consequence of deregulation of financial services, technological innovations and opening of the national banking systems to international competition. The banks in the Western Balkans countries were shielded from international competition for a long time. The emergence of the global market, technological innovations as well as the banking crises occurring in certain countries at that time forced the banks to change their ways of doing business, whereas the deregulation of banking operations at the national level enabled the entry of foreign banks into domestic markets. As a result of these processes, the difference between banks and non-banking financial institutions vanished, just like the difference in their fields of operations.

When the countries of the Western Balkans achieved the consensus on the necessity of privatizing their banking systems, it was followed by the activities which had an impact on the effects of the privatization, which included deciding on how to implement the process, whether through endogenous or exogenous privatization, the role of the foreign capital, whether to choose a strategic partner from the ranks of global banking and financial groups, which implied a dominant future owner or advocate the approach of a diversified ownership structure.

In financial theory, the efficiency of the implementation of privatization modalities was researched in numerous studies. Frydman (Frydman et al, 1999) made comparisons of the efficiency of endogenous and exogenous models of privatization. The research concluded that endogenous privatization, in the form of a distribution of shares to the employees, does not lead to any improvement in the performances of privatized banks (Ibid, pp. 1.154).

A research, which analyzed the impact of privatization on the efficiency of the banking system of a certain country, conducted by Buch (1997), indicated that the ownership structure of the banking system has an important role in the efficiency analysis. Its results show that, as a consequence of privatization, foreign banks operated more successfully in comparison with state-owned banks in the Western Balkans.

Deregulation and globalization of financial services brought about some dramatic changes when it comes to the share of foreign banks in the Western Balkans' banking systems, at the end of the last century and especially in the first decade of this century. Thus, concurrently with a decrease of the share of state-owned banks in the total number of banks, there has been a significant increase in the number of foreign 
izgubile osnovnu ulogu, funkciju prikupljanja slobodnih sredstava i njihovog plasiranja, čime je poverenje javnosti u bankarske sisteme izgubljeno zbog nemogućnosti deponenata da koriste svoja sredstva kao i zbog lošeg iskustva sa piramidalnim bankama $\mathrm{u}$ tom periodu. Zbog navedenog, u bankarskim sistemima zemalja Zapadnog Balkana sprovedene su reforme putem privatizacije državnih banaka i liberalizacije domaćeg finansijskog tržišta u odnosu na ulazak stranih banaka. U tranzicionim ekonomijama prisutne su tri faze u razvoju bankarskih sistema.

U prvoj fazi uspostavlja se sistem komercijalnih banaka kao akcionarskih društava koje zamenjuju monobankarske sisteme. Neke zemlje Zapadnog Balkana, odnosno Bugarska i Rumunija, bile su specifične, s obzirom da su bankarski sistemi u ovim državama doživeli transformaciju iz jedne institucije monobanke koja je imala ulogu i sprovođenja monetarne politike i obavljanja poslova komercijalnog bankarstva. Proces transformacije u prvoj fazi podrazumevao je u ovim državama formiranje tri državne banke - centralne, komercijalne i investicione od jedne državne banke. Sledeći korak bilo je formiranje više komercijalnih banaka u državnom vlasništvu.

Zemlje koje se analiziraju, a koje su bile deo SFRJ, nisu imale klasičan socijalistički monobankarski sistem, imajući u vidu da je postojalo samoupravno socijalističko društvo, pri čemu je model jugoslovenske privrede i društvenog sistema uspostavljen kao da je Jugoslavija izolovana zemlja. U unutrašnjem prometu društvenog sektora, platni promet se sprovodio preko Službe društvenog knjigovodstva, ali ne u poslovanju sa stanovništvom, kao i prometu društvenog sektora sa inostranstvom. Banke su poslovale shodno klasičnim principima likvidnosti, solventnosti i boniteta (Čolanović, u izvoru Matić, 2014), odnosno plasirale su kredite u skladu sa prikupljenim depozitima. Cilj banke bio je da ostvari dohodak u sferi društvene reprodukcije. Narodna banka SFRJ imala je emisionu, kreditnu i deviznu funkciju. Služba društvenog knjigovodstva (do 1991. godine), a zatim sa promenjenim nazivom Zavod za obračun i plaćanje (1992-2002) bila je deo bankarskog sistema i obavljala je poslove od opšteg društvenog interesa, poslove platnog prometa kao i kontrolu raspolaganja i trošenja društvenih sredstava.

Druga faza uključivala je restrukturiranje bankarskih portfolija i dokapitalizaciju banaka. Uspešnost restrukturiranja banaka podrazumeva je sledeće preduslove (Dinkić, Jelašić, 2001, str. 26.): a) unutrašnja politička podrška za realizaciju ovog procesa; b) razvoj opšte ekonomske situacije u zemlji; c) finansijska podrška međunarodne zajednice naporima da se izvrši restrukturiranje banaka; d) raspoloživost odgovarajućih finansijskih sredstava za ove namene; e) primena pravnog i institucionalnog okvira za regulisanje potraživanja i likvidaciju preduzeća, odnosno banaka; f) odgovarajući finansijski i kadrovski potencijal državne agencije za sanaciju banaka; g) socijalni program za zaposlene koji ostaju bez posla u bankarskom sektoru; h) koordinacija sa ministarstvima privatizacije i finansija.

Treća faza razvoja bankarskih sistema u zemljama Zapadnog Balkana uključivala je privatizaciju banaka. Proces privatizacije banaka u ovim zemljama uključivao je ulazak stranih banaka na navedena tržišta i pri tome odražavao želju velikih međunarodnih banaka i regionalnih banaka da prošire svoje poslovanje na profitabilnim tržištima, napore lokalnih vlasti da poboljšaju efikasnost i stabilnost finansijskih sistema, kao i da pomognu procesu smanjenja troškova dokapitalizacije domaćih banaka koje su imale ozbiljne probleme u svom poslovanju.

Kada je reč o ulasku stranih banaka na tržišta zemalja Zapadnog Balkana, prisutna je šira saglasnost $u$ pogledu pozitivnih efekata na privrede ovih zemalja. Strane banke uvode nove tehnologije $\mathrm{u}$ rad banaka, bolje koriste složene finansijske instrumente i tehnike, a imaju i lakši pristup međunarodnom tržištu kapitala i likvidnim izvorima.

Pri analizi posledica ulaska stranih banaka u zemlje Zapadnog Balkana, problemi mogu nastati u proceni efekata ovih kretanja, jer je teško razlikovati uticaj bankarskih reformi koje su navedene zemlje sprovele i šireg procesa liberalizacije i procesa otvaranja bankarskog sistema u odnosu na ulazak stranih banaka.

Poslovanje stranih banaka u zemljama Zapadnog Balkana razlikuje se i od poslovanja domaćih banaka i u tome što su strane banke 
banks present in the Western Balkans, along with some smaller changes in the number of domestic private banks.

\section{Periods in the Development of Banking Systems in the Western Balkan Countries}

The banking markets of the Western Balkans are insufficiently developed and small in comparison with the banking market of the European Union (Barjaktarović and Paunović, 2012, pp. 85). During the 1990s, banks lost their primary role, the function of harvesting and investing available funds, which led to the loss of the public confidence in the banking systems due to the inability of depositors to use their assets, and their bad experience with the pyramidal banking schemes in that period. As a result, in the banking systems in the Western Balkans, reforms have been implemented through the privatization of state banks and the liberalization of the domestic financial market in terms of the entry of foreign banks. In transition economies, the development of banking systems occurs in three stages.

In the first phase, a system of commercial banks is established, incorporated as joint-stock companies that replace mono-banking systems. Some Western Balkan countries, namely Bulgaria and Romania, faced a specific situation, as the banking systems in these countries experienced a transformation from a single mono-bank institution, which also played a role in both monetary policy and commercial banking. During the initial phase, the transformation process in these countries implied the formation of three state-owned banks: central, commercial and investment banks from a single state bank. The next step was the formation of multiple state-owned commercial banks.

The analyzed countries, which were part of the Socialist Federal Republic of Yugoslavia, did not have a classic socialist monetary system, bearing in mind that it was a socialist society based on self-management, with the model of the Yugoslav economy and the social system being established as if Yugoslavia were an isolated country. In the internal turnover of the social sector, the payment operations were carried out through the Social Accounting
Service, but not in the retail segment, nor in the social sector operations related to foreign trade. Banks operated in accordance with the classical principles of liquidity, solvency and creditworthiness (Čolanović, originally Matić, 2014), respectively, they placed loans in accordance with the collected deposits. The goal of a bank was to generate income in the sphere of social reproduction. The National Bank of the SFRY had the issuing, credit and foreign exchange functions. The Social Accounting Service (until 1991), and subsequently under the changed name of the Bureau for Clearing and Payments (1992-2002), was a part of the banking system and performed activities of general social interest, payment transactions as well as control of the disposal and spending of social funds.

The second phase involved the restructuring of bank portfolios and the recapitalization of banks. The success of bank restructuring implies the following prerequisites (Dinkić, Jelašić, 2001, p. 26): a) internal political support for the implementation of this process; $b$ ) development of the general economic situation in the country; c) financial support from the international community towards the bank restructuring efforts; d) availability of appropriate financial resources for these purposes; e) application of the legal and institutional framework for regulating the claims and liquidating enterprises or banks; f) appropriate financial and human resource potential of the State Agency for Bank Rehabilitation; g) social program for employees who are left unemployed in the banking sector; h) coordination with the ministries of privatization and finance.

The third phase of the development of the banking systems in the Western Balkan countries included the privatization of banks. The process of bank privatization in these countries included the entry of foreign banks into these markets, reflecting the desire of large international banks and regional banks to expand their operations into profitable markets, efforts by local authorities to improve the efficiency and stability of financial systems, as well as to facilitate the process of reducing the costs of additional capitalization of domestic banks that had serious problems in their business operations.

As for the entry of foreign banks into the markets of the Western Balkan countries, there 
u manjoj meri zavisne od prikupljanja lokalnih depozita, jer imaju lakši pristup novčanom tržištu ili dokapitalizaciji od strane matične banke. Međutim, kako je globalna finansijska kriza prouzrokovala problem likvidnosti banaka na novčanom tržištu kao i to da su mnoge matične banke banaka u zemljama Zapadnog Balkana zabeležile gubitke u svom poslovanju, prikupljanje novih depozita u zemljama Zapadnog Balkana je dobilo podjednak značaj kako za domaće banke tako i za strane banke u njihovom povećanju kreditne aktivnosti.

Bankarski sektori u zemljama Zapadnog Balkana ulaskom stranih banaka povećali su značajno raspoložive finansijske usluge koje pružaju, od kojih mnoge pre toga nisu bile pružane. Da li su pri tome banke postale pokretač ekonomskog razvoja u navedenim zemljama u tranziciji, ostaje otvoreno pitanje. Mnoge velike kompanije, naročito u novim članicama EU, u stanju su da koriste prednost povećane integracije evropskog tržišta kapitala i mogućnost da pribave dodatna finansijska sredstva izvan svojih zemalja. Nagli rast kreditne aktivnosti banaka u nekim zemljama Zapadnog Balkana bio je osnov zabrinutosti, imajući u vidu povećanje rizika u celom bankarskom sistemu tih zemalja. Pri tome, većina kredita stranih banaka u pomenutim zemljama odobrena je $\mathrm{u}$ stranim valutama kao što su u mnogim slučajevima depoziti banaka takođe u stranoj valuti, što utiče na pojavu deviznog rizika. Iako su depoziti ovih banaka uglavnom u evrima, devizni rizik nije izbegnut, s obzirom na to da kretanje kursa evra u odnosu na domaću valutu može da dovede u pitanje sposobnost dužnika da vrate kredite sa deviznom klauzulom ili kredite odobrene u stranoj valuti.

Ovi rizici zaista su problem sa kojim se suočavaju banke u zemljama Zapadnog Balkana i karakteristični su za male, otvorene privrede i čiji su bankarski sistemi u procesu vlasničke transformacije. Pri tome, međusobna povezanost između konsolidacije banaka i koncentracije u okviru bankarskog sektora prisutna je u svim malim bankarskim sektorima. Iako proces konsolidacije odstranjuje neefikasne banke, on u isto vreme povećava koncentraciju u bankarskom sektoru, koja može da ograniči konkurenciju među bankama i stvori sistemski rizik.

\section{Vlasnička transformacija bankarskih sistema}

Na ovom mestu ukazaćemo na stanje $u$ kome su se nalazile pojedine zemlje Zapadnog Balkana pre prelaska svojih bankarskih sistema u tržišne, kao i na sam proces transformacije, pri čemu Zapadni Balkan u analizi uključuje Crnu Goru, BiH, Hrvatsku, Makedoniju i Srbiju.

Crna Gora se suočila sa pojavom piramidalnih institucija tokom devedesetih godina prošlog veka. Ovakva kretanja uticala su na bankarski sektor, potpuno urušavajući poverenje u njega. Proces konsolidacije bankarskog sektora počeo je 2001. godine. Dve banke su zatvorene, a nekoliko većih banaka je nacionalizovano i kasnije privatizovano od strane inostranih banaka. Najvećim bankama je privremeno rukovodila centralna banka, tokom čega su njihovi bilansi očišćeni odstranjivanjem loše aktive i prodajom stranim investitorima tokom 2003. godine. Poverenje javnosti u bankarski sistem je dodatno povećano uspostavljenjem Fonda za osiguranje depozitau2006. godini. Transformacija vlasništva bankarskog sistema Crne Gore ubrzana je 2005. godine, kada je Societe Generale banka kupila Podgoričku banku. Posle godinu dana usledile su privatizacije Nikšićke, Pljevaljske i Hipotekarne banke. Na dan 30.06.2017. godine, u Crnoj Gori je poslovalo 15 banaka pri čemu se 75,50\% aktive odnosi na banke u vlasništvu stranih lica.

Specifičnost Bosne i Hercegovine ogleda se $\mathrm{u}$ tome što ima bankarski sistem $\mathrm{u}$ dva entiteta, Federaciji Bosne i Hercegovine i Republici Srpskoj. Kašnjenje u restrukturiranju bankarskog sistema prouzrokovano je i različitim prioritetima dva entiteta. Federalna bankarska agencija kao nadzorni organ za poslovanje banaka u Federaciji Bosne i Hercegovine počela je sa radom 1997. godine dok je Bankarska agencija u Republici Srpskoj počela da radi godinu dana kasnije. Proces privatizacije banaka uključivao je transfer loše aktive u Ministarstvo finansija. Postepeni oporavak bankarskog sistema počeo je od 2000. godine u oba entiteta. Najveće banke u Federaciji BiH su posle izvršene transformacije, odnosno privatizacije, UniCredit banka Mostar, Reiffeisen banka Sarajevo i Banca Intesa Sarajevo. U Federaciji BiH na dan 30.06.2017. godine poslovalo je 15 banaka, pri čemu se 
is a broad agreement regarding the positive effects on the economies of these countries. Foreign banks introduce new technologies into the banks' operations, better utilize complex financial instruments and techniques, and have easier access to the international capital market and liquid sources.

When analyzing the consequences of the entry of foreign banks into the Western Balkan countries, problems can arise in assessing the effects of these developments, because it is difficult to differentiate the influence of banking reforms that the countries have implemented and the broader liberalization process and the process of the banking systems' opening towards the entry of foreign banks.

The performance of foreign banks in the Western Balkan countries differs from the operations of domestic banks in a sense that foreign banks are to a lesser extent dependent on the collection of local deposits, as they have easier access to the financial market or additional capitalization by the parent bank. However, given that the global financial crisis caused the problem of the banks' liquidity on the financial market, and that many parent banks in the Western Balkan countries experienced operating losses, the collection of new deposits in the Western Balkan countries was equally important both for domestic banks and for foreign banks in their increase of credit activity.

With the entry of foreign banks, the banking sectors in the Western Balkan countries have significantly increased the available financial services they provide, many of which were previously unavailable. Whether the banks have become the drivers of economic development in these countries in transition remains an open question. Many large companies, especially in the new EU member states, are able to take advantage of the increased integration of the European capital market and the ability to obtain additional funding outside their own countries. The sudden rise in the banks' lending activity in some Western Balkan countries was a reason for concern, given the increased risk across the whole banking system of these countries. Additionally, most of the loans approved by foreign banks in the aforementioned countries were approved in foreign currencies, as in many cases bank deposits were also in foreign currency, causing the occurrence of foreign exchange risk. Although the deposits of these banks are mainly in euros, the foreign exchange risk is not entirely avoided, as the movement of the euro exchange rate against the domestic currency may jeopardize the ability of the borrowers to repay loans with a foreign currency clause or loans issued in foreign currency.

The aforementioned risks are the real problems that banks face in the Western Balkan countries and are characteristic of small, open economies and economies whose banking systems are in the process of ownership transformation. In addition, the interconnection between bank consolidation and concentration within the banking sector is present in all small banking sectors. Although the process of consolidation eliminates inefficient banks, it simultaneously increases the concentration in the banking sector, which can inhibit competition among the banks and generate a systemic risk.

\section{Ownership Transformation of the Banking Systems}

In the following analysis, we will describe the situation in which certain Western Balkan countries found themselves before the transition of their banking systems to the market-oriented ones, as well as the process of transformation itself. In this analysis the Western Balkans include Montenegro, Bosnia and Herzegovina, Croatia, Macedonia and Serbia.

Montenegro faced the emergence of pyramidal scheme institutions during the 1990s. Such developments have affected the banking sector by completely eroding the public confidence in it. The process of the banking sector consolidation started in 2001. Two banks were closed, and several major banks were nationalized and later privatized by foreign banks. The largest banks were temporarily managed by the central bank, during which time their balances were cleared by removing bad assets and selling them to foreign investors in the course of 2003. Public confidence in the banking system was further increased by the establishment of the Deposit Insurance Fund in 2006. The ownership transformation of the banking system of Montenegro was accelerated in 2005, when Societe General Bank bought 
90,3\% odnosilo na banke u vlasništvu stranih lica. U Republici Srpskoj su najveće banke posle izvršene transformacije, odnosno privatizacije, Addiko banka Banja Luka, Nova banka Banja Luka i UniCredit banka Banja Luka. U Republici Srpskoj na dan 30.06.2017. godine poslovalo je 8 banaka, pri čemu se $66,4 \%$ aktive odnosi na banke u vlasništvu stranih lica.

Hrvatska je imala nesolventni bankarski sistem tokom devedesetih godina prošlog veka, domaća štednja je bila nedostupna građanima ili je bila prenesena u druge države. Prvi Zakon o bankama usvojen je 1993. godine i uspostavio je minimalne zahteve u pogledu visine kapitala i liberalizovao ulazak stranih banaka. Godine 1994. osnovana je Državna agencija za sanaciju i osiguranje depozita koja je započela sa sanacijom najvećih banaka po principu case-bycase. Proces sanacije banaka zahtevao je veliki iznos sredstava. Imajući u vidu da je veći deo depozita banaka bio u stranoj valuti, banke su bile posebno osetljive na kretanja na deviznim tržištima. Ovo je naročito bilo prisutno tokom međunarodne finansijske krize 1997-1998. godine, kada je bio ograničen pristup domaćih banaka inostranim kreditorima. Bankarski sektor je zatim doživeo značajne promene izlaskom malih i srednjih banaka iz bankarskog sistema dok je istovremeno povećan ulazak stranih investitora koji su kupovali domaće banke. U Republici Hrvatskoj na dan 30.06.2017. godine poslovalo je 26 banaka, pri čemu se $85 \%$ aktive odnosi na banke u vlasništvu stranih lica.

Proces privatizacije banaka u Makedoniji odvijao se paralelno sa procesom privatizacije preduzeća. Zakon o bankama stupio je na snagu 1993. godine i utvrdio minimalnu visinu kapitala koje banke moraju da poseduju. Banke su i dalje kreditirale kompanije koje posluju sa gubitkom ili sa malo svojih raspoloživih sredstava, tako da su svoja potraživanja pretvarala $\mathrm{u}$ akcije tih kompanija. U cilju rešavanja ovih problema, vlada je 1995. godine donela mere sa ciljem sanacije i restrukturiranja bankarskog sektora. Agencija za sanaciju banaka je prenela loše kredite iz kompanija i uključila ih u proces sanacije banaka. Troškovi sanacije banaka iznosili su $42 \%$ BDP-a. U Republici Makedoniji na dan 30.06.2017. godine poslovalo je 15 banaka, pri čemu se $70,3 \%$ aktive odnosi na banke u vlasništvu stranih lica.

U okviru regiona Zapadnog Balkana, najveće kašnjenje u transformaciji bankarskog sistema bilo je prisutno u Srbiji. Ovo podrazumeva da se izgubljena dekada devedesetih godina prošlog veka ne odnosi samo na opšte ekonomske reforme, već i na proces transformacije bankarskog sektora. Tokom devedesetih godina godina prošlog veka nije se krenulo $u$ proces transformacije bankarskog sektora. $\mathrm{U}$ godinama kada je bila hiperinflacija vrednost dinarske aktive i pasive drastično je smanjena u bilansima banaka. U drugoj polovini devedesetih godina prošlog veka, bankarski sektor je bio u jako lošem stanju, jer je učešće loših kredita iznosilo skoro 90\% svih kredita, uz negativni koeficijenat adekvatnosti kapitala.

Suštinske reforme u bankarskom sektoru u Srbiji počele su od 2000. godine. Sledeće godine izvršena je procena stanja bankarskog sistema i napravljena strategija transformacije koju su pomogle i podržale međunarodne finansijske institucije. Kao i u drugim zemljama Zapadnog Balkana, poverenje u bankarski sistem bilo je vrlo malo, prvenstveno zahvaljujući lošem iskustvu zamrznutih deviznih sredstava i piramidalnim finansijskim institucijama koje su poslovale tokom devedesetih godina prošlog veka.

U 2002. godini država izdaje obveznice sa ciljem da reši problem vraćanja građanima devizne štednje koja je bila u bankama, čime je otpočeo proces transformacije bankarskog sistema. Takođe, nad više banaka izvršen je stečaj, a kod banaka srednje veličine država je pretvorila svoja potraživanja u akcijski kapital $\mathrm{u}$ ovim bankama i privatizovala ih prodajom inostranim bankama.

Bankarski sistem Srbije prošao je kroz reformu 2002. godine, što je uključivalo i smanjenje broja banaka sa 86 koliko ih je bilo 2001. godine na 31 koliko ih je poslovalo krajem juna 2017. godine. 
Podgorička Bank. A year later, the privatization of Nikšićka, Pljevaljska and Hipotekarna banka followed. On 30 June 2017, 15 banks operated in Montenegro, where $75.50 \%$ of assets belonged to banks owned by foreign entities.

The distinctiveness of Bosnia and Herzegovina is reflected in the fact that it has a banking system based in two entities, the Federation of Bosnia and Herzegovina and the Republic of Srpska. The delay in the restructuring of the banking system was caused by the different priorities of the two entities. The Federal Banking Agency, as the supervisory body for banking operations in the Federation of Bosnia and Herzegovina, started operating in 1997, whereas the Banking Agency in the Republic of Srpska started operating a year later. The process of bank privatization involved the transfer of bad assets to the Ministry of Finance. The gradual recovery of the banking system began in 2000 in both entities. The largest banks in the Federation of Bosnia and Herzegovina, after the transformation, i.e. privatization, were UniCredit Bank Mostar, Raifeissen Bank Sarajevo and Banca Intesa Sarajevo. In the Federation of B\&H, 15 banks operated on 30 June 2017, 90.3\% of which were owned by foreign owned banks. After the privatization, the largest banks in the Republic of Srpska are Addiko banka Banja Luka, Nova banka Banja Luka and UniCredit Bank Banja Luka. On 30 June 2017, 8 banks operated in the Republic of Srpska, where $66.4 \%$ of assets belonged to banks owned by foreign entities.

Croatia had an insolvent banking system during the 1990s, where domestic savings were inaccessible to citizens or transferred to other countries. The first Law on Banks was adopted in 1993 setting the minimum requirements regarding the level of capital, and liberalizing the entry of foreign banks. In 1994, the State Agency for Bank Rehabilitation and Deposit Insurance was established, which started the remediation of the largest banks according to the case-by-case principle. The process of bank bail-outs required a large amount of funds. Bearing in mind that most of the banks' deposits were in foreign currency, banks were particularly sensitive to the movements at the foreign exchange markets. This was particularly present during the 1997-1998 international financial crisis, when the domestic banks' access to foreign creditors was restricted. The banking sector subsequently experienced significant changes as the small and mediumsized banks started exiting the banking system, while at the same time the number of foreign investors purchasing domestic banks increased. On 30 June 2017, 26 banks were operating in the Republic of Croatia, where $85 \%$ of assets belonged to the banks owned by foreign entities.

The process of bank privatization in Macedonia took place in parallel with the privatization of enterprises. The Law on Banks came into force in 1993 and determined the minimum required amount of capital for the banks. The banks continued lending to lossmaking companies or those with few available funds of their own, thus turning their claims into the shares of these companies. In order to solve these problems, in 1995 the government adopted measures aimed at the rehabilitation and restructuring of the banking sector. The Agency for Bank Rehabilitation transferred bad loans from companies and included them in the process of bank rehabilitation. The costs of remediation of banks amounted to $42 \%$ of GDP. On 30 June 2017, 15 banks were operating in the Republic of Macedonia, with $70.3 \%$ of assets belonging to banks owned by foreign entities.

Within the region of the Western Balkans, Serbia experienced the biggest delay in the transformation of the banking system. This implies that the lost decade of the 1990s not only applies to economic reforms in general, but to the process of transformation of the banking sector as well. The 1990s did not see the launch of the banking sector transformation. In the hyperinflation years, the value of dinardenominated assets and liabilities was drastically reduced in the balance sheets of banks. In the second half of the 1990s, the banking sector was in a very poor condition, because the share of non-performing loans accounted for almost $90 \%$ of total loans, accompanied with a negative capital adequacy ratio.

Substantial reforms in the banking sector in Serbia began in 2000. The next year, the state of the banking system was assessed and the strategy of transformation drafted with the help of international financial institutions. As in other Western Balkan countries, the trust in 
Tabela 1. Bankarski sistem u Srbiji

\begin{tabular}{|l|c|c|c|c|c|c|c|}
\hline \multirow{2}{*}{ Kraj godine } & \multirow{2}{*}{$\begin{array}{c}\text { Ukupan } \\
\text { broj } \\
\text { banaka }\end{array}$} & \multicolumn{3}{|c|}{$\begin{array}{c}\text { Stranke većinsko } \\
\text { vlasništvo }\end{array}$} & \multicolumn{2}{c|}{$\begin{array}{c}\text { Domaće većinsko } \\
\text { vlasništvo }\end{array}$} & \multicolumn{2}{c|}{$\begin{array}{c}\text { Banke sa državnim } \\
\text { vlasništvom }\end{array}$} \\
\cline { 3 - 8 } & & Broj & $\begin{array}{c}\text { Učešće u } \\
\text { bilansnoj sumi } \\
\text { (u \%) }\end{array}$ & Broj & $\begin{array}{c}\text { Učešće u } \\
\text { bilansnoj sumi } \\
\text { (u\%) }\end{array}$ & \multirow{2}{*}{ Broj } & $\begin{array}{c}\text { Učešće u } \\
\text { bilansnoj sumi } \\
\text { (u \%) }\end{array}$ \\
\hline 2002. & 50 & 12 & 27,0 & 15 & 23,6 & 23 & 49,4 \\
\hline 2003. & 47 & 16 & 38,4 & 16 & 27,5 & 15 & 34,1 \\
\hline 2004. & 43 & 11 & 37,7 & 18 & 26,2 & 14 & 36,1 \\
\hline 2005. & 40 & 17 & 66,0 & 12 & 10,1 & 11 & 23,9 \\
\hline 2006. & 37 & 22 & 78,7 & 7 & 6,5 & 8 & 14,8 \\
\hline 2007. & 35 & 21 & 75,5 & 6 & 8,8 & 8 & 15,7 \\
\hline 2008. & 34 & 20 & 75,3 & 6 & 8,7 & 8 & 16,0 \\
\hline 2009. & 34 & 20 & 74,3 & 4 & 8,2 & 10 & 17,5 \\
\hline 2010. & 33 & 21 & 74,0 & 4 & 8,0 & 8 & 18,0 \\
\hline 2011. & 33 & 21 & 74,0 & 4 & 8,0 & 8 & 18,0 \\
\hline 2012. & 32 & 21 & 75,0 & 3 & 7,0 & 8 & 18,0 \\
\hline 2013. & 30 & 21 & 74,4 & 3 & 6,8 & 6 & 18,8 \\
\hline 2014. & 29 & 21 & 74,4 & 2 & 6,3 & 6 & 19,3 \\
\hline 2015. & 30 & 23 & 76,1 & 1 & 5,9 & 6 & 18,0 \\
\hline 2016. & 30 & 22 & 76,7 & 2 & 6,0 & 6 & 17,3 \\
\hline 2017. II kvartal & 31 & 21 & 75,3 & 4 & 8,1 & 6 & 16,6 \\
\hline
\end{tabular}

Izvor: NBS, Sektor za kontrolu poslovanja banaka: Bankarski sektor u Srbiji, kvartalni izveštaji za više godina

Transformaciju bankarskog sistema Srbije karakterišeu prvom redu smanjenje broja ukupnih banaka. Takođe, $\mathrm{u}$ prvim godinama prisutno je smanjenje učešća domaćih državnih banaka i povećanje učešća banaka u kome su vlasnici strana pravna lica u ukupnoj aktivi, da bi se od 2005. godine učešće stranih banaka stabilizovalo na oko $75 \%$ učešća u ukupnoj aktivi bankarskog sistema. Bankarski sistem Srbije beleži zadovoljavajući stepen konkurencije i nisku koncentraciju aktivnosti, jer Herfindal-Hiršmanovom indeks ukazuje na odsustvo koncentracije u svim kategorijama od kredita, depozita do prihoda banaka.

$\mathrm{U}$ pogledu neto bilansne aktive i ukupno odobrenih kredita, drugi kvartal 2017. godine karakterišu neznatne promene tržišnog učešća deset najvećih banaka na dan 30.06.2017. godine i to iznosi $77,5 \%$ i $74,7 \%$. Proces ukrupnjavanja banaka u Srbiji još nije završen i može se očekivati da se smanji učešće državnih banaka, privatizacijom navedenih banaka.

Koncentracija u bankarskom sistemu Srbije je u dužem periodu zadovoljavajuća. Tako, vrednost Herfindal-Hiršmanovog indeksa pokazuje na odsustvo koncentracije. Prisutna koncentracija $\mathrm{u}$ bankarskom sistemu Srbije u ukupnoj bilansnoj sumi i kreditima (u \%) prikazana je u tabelama u nastavku.

Tabela 2. Aktiva banaka

\begin{tabular}{|l|c|c|c|c|}
\hline & 2014. & 2015. & 2016. & 2017. II kvartal \\
\hline Prvih 5 banaka & 53,6 & 54,2 & 54,7 & 54,8 \\
\hline Prvih 10 banaka & 76,3 & 76,8 & 77,4 & 77,5 \\
\hline HHI koeficijent & 794 & 796 & 813 & 804 \\
\hline Ukupan broj banaka & 29 & 30 & 30 & 31 \\
\hline
\end{tabular}

Izvor: NBS, Sektor za kontrolu poslovanja banaka: Bankarski sektor u Srbiji, kvartalni izveštaji za više godina

Tabela 3. Ukupni krediti banaka

\begin{tabular}{|l|c|c|c|c|}
\hline & 2014. & 2015. & 2016. & 2017. II kvartal \\
\hline Prvih 5 banaka & 53,9 & 52,7 & 51,2 & 51,2 \\
\hline Prvih 10 banaka & 75,4 & 75,7 & 74,7 & 74,7 \\
\hline HHI koeficijent & 771 & 763 & 736 & 731 \\
\hline Ukupan broj banaka & 29 & 30 & 30 & 31 \\
\hline
\end{tabular}

Izvor: NBS, Sektor za kontrolu poslovanja banaka: Bankarski sektor u Srbiji, kvartalni izveštaji za više godina

Koeficijent koncentracije banaka pokazatelj je prisutne koncentracije u bankarskom sistemu, s obzirom da predstavlja učešće poslovanja 
the banking system was very low, primarily due to the bad experience with frozen foreign exchange assets and pyramidal scheme financial institutions that operated during the 1990s.

In 2002, the state issued bonds with the aim of solving the problem of returning the FX savings held in the banks, which marked the beginning of the banking system transformation process. Moreover, bankruptcy proceedings were carried out over several banks, and in the medium-sized banks, the state turned its claims into equity and privatized them by selling them to foreign banks.

The Serbian banking system underwent a reform in 2002, which included a decrease in the number of banks from 86 in 2001 to 31 at the end of June 2017. banks stabilized at about $75 \%$ of the share in the total assets of the banking system. The banking system of Serbia records a satisfactory degree of competition and a low concentration of activities, since the Herfindahl-Hirschman Index indicates a lack of concentration in all categories, ranging from loans and deposits to the banks' profit.

With regard to net balance sheet size and total loans issued, the second quarter of 2017 was characterized by some slight changes in the market share of the ten largest banks, and as of 30 June 2017 it stands at $77.5 \%$ and $74.7 \%$ respectively. The process of bank mergers in Serbia has not yet been completed, and the participation of state-owned banks is expected to decline, after they get privatized, too.

Table 1. The banking system in Serbia

\begin{tabular}{|c|c|c|c|c|c|c|c|}
\hline \multirow{3}{*}{$\begin{array}{c}\text { End of the } \\
\text { year }\end{array}$} & \multirow{3}{*}{$\begin{array}{c}\text { Total } \\
\text { number of } \\
\text { banks }\end{array}$} & \multicolumn{4}{|c|}{ Privately owned banks } & \multirow{2}{*}{\multicolumn{2}{|c|}{ State-owned banks }} \\
\hline & & \multicolumn{2}{|c|}{ Majority forign-owned } & \multicolumn{2}{|c|}{ Majority domestic-owned } & & \\
\hline & & Number & $\begin{array}{c}\text { Balance share } \\
(\%)\end{array}$ & Number & $\begin{array}{c}\text { Balance share } \\
(\%)\end{array}$ & Number & $\begin{array}{c}\text { Balance share } \\
(\%)\end{array}$ \\
\hline 2002 & 50 & 12 & 27.0 & 15 & 23.6 & 23 & 49.4 \\
\hline 2003 & 47 & 16 & 38.4 & 16 & 27.5 & 15 & 34.1 \\
\hline 2004 & 43 & 11 & 37.7 & 18 & 26.2 & 14 & 36.1 \\
\hline 2005 & 40 & 17 & 66.0 & 12 & 10.1 & 11 & 23.9 \\
\hline 2006 & 37 & 22 & 78.7 & 7 & 6.5 & 8 & 14.8 \\
\hline 2007 & 35 & 21 & 75.5 & 6 & 8.8 & 8 & 15.7 \\
\hline 2008 & 34 & 20 & 75.3 & 6 & 8.7 & 8 & 16.0 \\
\hline 2009 & 34 & 20 & 74.3 & 4 & 8.2 & 10 & 17.5 \\
\hline 2010 & 33 & 21 & 74.0 & 4 & 8.0 & 8 & 18.0 \\
\hline 2011 & 33 & 21 & 74.0 & 4 & 8.0 & 8 & 18.0 \\
\hline 2012 & 32 & 21 & 75.0 & 3 & 7.0 & 8 & 18.0 \\
\hline 2013 & 30 & 21 & 74.4 & 3 & 6.8 & 6 & 18.8 \\
\hline 2014 & 29 & 21 & 74.4 & 2 & 6.3 & 6 & 19.3 \\
\hline 2015 & 30 & 23 & 76.1 & 1 & 5.9 & 6 & 18.0 \\
\hline 2016 & 30 & 22 & 76.7 & 2 & 6.0 & 6 & 17.3 \\
\hline 2017 Q2 & 31 & 21 & 75.3 & 4 & 8.1 & 6 & 16.6 \\
\hline
\end{tabular}

Source: NBS, Banking Supervision Department: Banking Sector in Serbia, quarterly reports for several years

The transformation of the banking system of Serbia is characterized primarily by a decrease in the overall number of banks. Also, in the first few years there was a decrease in the share of domestic state-owned banks and an increase in the share of banks fully owned by foreign legal entities, so that since 2005, the share of foreign
The long-term level of concentration in the banking system of Serbia is satisfactory. Thus, the value of the Herfindahl-Hirschman Index shows the absence of concentration. The present concentration in the banking system of Serbia in the total balance sheet size and loans (in \%) is shown in the following tables: 
određenog broja banaka na tržištu. Učešće pet najvećih banaka u bankarskom sistemu Srbije u pogledu aktive, krajem juna 2017. godine bilo je $54,8 \%$ i ono ima tendenciju porasta $\mathrm{u}$ odnosu na kraj 2014, 2015. odnosno 2016. godine. Sa druge strane, učešće pet najvećih banaka po visini ukupno odobrenih kredita krajem juna 2017. godine bilo je 51,2\% $\mathrm{i}$ ima tendenciju smanjenja $\mathrm{u}$ poređenju sa krajem 2014. i 2015. godine, što ukazuje da je porast učešća prvih pet najvećih banaka u ukupnoj aktivi banaka bio praćen njihovim smanjenjem u ukupno odobrenim kreditima. Ovako veliko učešće pet najvećih banaka u aktivi i ukupnim kreditima može da dovede do zaključka da u bankarskom sistemu Srbije nije prisutna konkurencija, međutim, jedan od najčešće korišćenih pokazatelja konkurencije - Herfindal-Hiršmanov (HHI) indeks, koji je tokom posmatrane četiri godine bio ispod 1000, svedoči o postojanju savršene konkurencije na tržištu. Nasuprot tome, vrednosti ovog indeksa u rasponu od 1000 do 1800 sugerišu da se radi o oligopolskom tržištu, a vrednosti iznad 1800 ukazuju da je reč o monopolskom tržištu.

Ukupna bilansna suma krajem juna 2017. godine iznosila je 3.221,0 miljardi dinara, što predstavlja povećanje za $0,4 \%$ u odnosu na stanje krajem marta 2017. godine. Najveći deo aktive predstavljaju krediti i potraživanja (62,3\%), dok kod pasive najveće učešće beleže primljeni depoziti $(69,1 \%)$, sopstveni izvori finansiranja (20,3\%) i primljeni krediti $(7,6 \%)$.

Kada se posmatra struktura banaka $u$ pogledu vlasništva krajem juna 2017. godine, došlo je do neznatnog povećanja vlasništva domaćih lica (sa $23,5 \%$ na $24,7 \%$ ). Do promene je došlo tako što je jedna strana banka prešla u vlasništvo domaćih pravnih lica. Međutim, to nije dovelo u pitanje dominantno učešće banaka u vlasništvu stranih lica (sa 76,5\% na 75,3\%).
Osim navedenih sedam banaka kod kojh je došlo do promene vlasnika i gde država više nije većinski vlasnik, u 2015. godini Halkbanka iz Turske kupila je 98,88\% akcija Čačanske banke a.d. Čačak i na taj način postala većinski vlasnik navedene banke.

\section{Posledice poslovanja stranih banaka tokom finansijske krize na bankarske sisteme Zapadnog Balkana}

Poslovanje zapadnoevropskih banaka $\mathrm{u}$ zemljama Zapadnog Balkana u početku nije bilo pod uticajem finansijske krize koja je pogodila razvijene zemlje Zapada, već su se njene posledice osećale krajem 2008. godine kada je došlo do stečaja banke Lehman Brothers u SAD. Naime, kao posledica gubitka poverenja na finansijskim tržištima, multinacionalne banke su značajno smanjivale svoje poslovanje u zemljama Zapadnog Balkana.

U finansijski integrisanoj svetskoj privredi, širenje negativnih kretanja dešava se na različite načine, na prvom mestu tu je međugranično kreditiranje, zatim kreditna aktivnost banke kćeri matične bankei kreditiranje preko domaćih banaka koje se zadužuju na međunarodnom finansijskom tržištu.

Generalno govoreći, strane banke su u većoj meri vezane za poslovanje svojih klijenata $\mathrm{u}$ matičnim zemljama zbog odobrenih dugoročnih kredita. Ovo pruža delimično objašnjenje zašto su ove banke uspešnije reagovale na krizu. Drugi autori (Berglof, u izvoru Kaufhold, 2013, 
Table 2. Banks' assets

Source: NBS, Banking Supervision Department: Banking Sector in Serbia, quarterly reports for several years

\begin{tabular}{|l|c|c|c|c|}
\hline & 2014 & 2015 & 2016 & Q2 2017 \\
\hline First 5 banks & 53.6 & 54.2 & 54.7 & 54.8 \\
\hline First 10 banks & 76.3 & 76.8 & 77.4 & 77.5 \\
\hline HHI coefficient & 794 & 796 & 813 & 804 \\
\hline Total number if banks & 29 & 30 & 30 & 31 \\
\hline
\end{tabular}

Tabela 3. Ukupni krediti banaka

\begin{tabular}{|l|c|c|c|c|}
\hline & 2014 & 2015 & 2016 & Q2 2017 \\
\hline First 5 banks & 53.9 & 52.7 & 51.2 & 51.2 \\
\hline First 10 banks & 75.4 & 75.7 & 74.7 & 74.7 \\
\hline HHI coefficient & 771 & 763 & 736 & 731 \\
\hline Total number if banks & 29 & 30 & 30 & 31 \\
\hline
\end{tabular}

Source: NBS, Banking Supervision Department: Banking Sector in Serbia, quarterly reports for several years index ranging from 1000 to 1800 represents an oligopolistic market, and values over 1800 point towards a monopoly market.

The total balance sum at the end of June 2017 amounted to 3,221.0 billion dinars, an increase of $0.4 \%$ in comparison with the end of March 2017. Most of the assets were loans and receivables $(62.3 \%)$, while the largest shares in liabilities went to received deposits (69.1\%), own sources of financing $(20.3 \%)$ and loans received $(7.6 \%)$.

When considering the structure of banks in terms of ownership at the end of June 2017, there was a slight increase in the domestic entities' ownership (from $23.5 \%$ to $24.7 \%$ ). The change came as one foreign bank was transferred into ownership of domestic legal entities. However, this did not call into

The coefficient of concentration of banks is an indicator of the concentration present in the question the dominant participation of banks owned by foreign entities (from $76.5 \%$ to $75.3 \%$ ). banking system, since it represents the market share of a certain number of banks on the market. The share of the five largest banks in the banking system of Serbia in terms of assets, at the end of June 2017 was 54.8\%, with a tendency to increase compared to the end of 2014, 2015 and 2016 respectively.

On the other hand, the participation of the five largest banks in the amount of total approved loans at the end of June 2017 was $51.2 \%$, with a tendency to decrease compared to the end of 2014 and 2015, indicating that the increase in the participation of the top five banks in total assets banks was followed by their decrease in total loans issued. Such a large share of the five largest banks in assets and total loans can lead to the conclusion that there is an absence of competition in the banking system of Serbia. One of the most frequently used indicators of competition is the HerfindahlHirschman Index (HHI), and its observed value for four years was under 1000, which speaks in favor of the existence of perfect competition in the market. As opposed to that, the value of this
In addition to the seven banks that have changed ownership and where the state is no longer the majority owner, in 2015 Halkbank from Turkey bought $98.88 \%$ of shares of Čačanska banka a.d. Čačak, hence becoming the majority owner of the aforementioned bank.

\section{Consequences of Foreign Banks' Operations during the Financial Crisis on the Banking Systems of the Western Balkans}

The performance of the banks from Western Europe operating in the countries of the Western Balkans was initially not affected by the financial crisis that hit the developed countries of the West, but its effects were felt at the end of 2008, when the Lehman Brothers bankruptcy 
str. 27) ukazuju da je veće učešće stranih banaka u zemljama Zapadnog Balkana blisko povezano sa manjim smanjenjem prekograničnog kreditiranja. Takođe, nivo proizvodnje je opadao manje u zemljama Zapadnog Balkana u kojima su strane banke prisutne u značajnijoj meri, što je pokazatelj da prisustvo stranih banaka u zemljama Zapadnog Balkana utiče na smanjenje posledica finansijske krize na ove zemlje i povećava finansijsku stabilnost.

U pogledu uticaja krize na poslovanje stranih banaka u zemljama Zapadnog Balkana postoje različita mišljenja. Prvo, da kreditna aktivnost stranih banaka $\mathrm{u}$ ovim zemljama ne beleži smanjenje u uslovima krize, nego da u takvim okolnostima krediti imaju rast (Goldberg, u izvoru Allen F. i saradnici, 2017). Objašnjenje ovome ogleda se u činjenici da se strane banke manje oslanjaju na prikupljanje depozita u navedenim zemljama i da su više orijentisane na strane izvore svog poslovanja. Shodno tome, njihova ponuda kredita je manje prociklična. Takođe, strane banke imaju drugačije klijente u poređenju sa domaćim bankama. Drugi autori (De Haas i Lelyveld, u izvoru Allen. F. i saradnici, 2017, str. 495) ističu suprotan stav, naime da evropske matične banke nisu bile značajni izvori dodatnih sredstava svojim bankama kćerima u zemljama Zapadnog Balkana tokom krize. Naglašavaju i da je smanjenje kreditne aktivnosti banaka kćeri tri puta bilo veće nego smanjenje kreditne aktivnosti domaćih banaka tokom krize 20082009. godine. Za razliku od gore navedenih stavova, izvesni autori (Dages, u izvoru Allen. F i saradnici, 2017) ukazuju da se domaće banke i strane banke u zemljama Zapadnog Balkana sa malim učešćem nenaplativih kredita ponašaju slično, što upućuje na zaključak da uspešnost banke odnosno njeno finansijsko stanje, a ne vlasništvo, predstavljaju ključni faktor u poslovanju banaka u navedenim zemljama.

Krajem 2008. godine bila je prisutna zabrinutost $\mathrm{u}$ pogledu bankarskih sistema evropskih zemalja u tranziciji, u koje spadaju i zemlje Zapadnog Balkana. Povećana kreditna aktivnost banaka $\mathrm{u}$ regionu pre krize uticala je na preveliku zaduženost mnogih privatnih kompanija i u zemljama Zapadnog Balkana. Smanjeno finansiranje od strane matičnih banaka ka njihovim bankama ćerkama nije uticalo samo na kreditnu aktivnost banaka ćerki već je dovelo do snažne makroekonomske destabilizacije. Novembra iste godine velike evropske banke su predložile Evropskoj komisiji, EBRD i EIB, da se preduzme koordinarajuća akcija u odnosu na probleme sa kojima se suočavaju zemlje Zapadnog Balkana, kao i da se obezbedi dovoljni nivo sredstava za banke koje posluju $\mathrm{u}$ ovom regionu. $\mathrm{U}$ tom cilju, pokrenuta je Bečka inicijativa 2008. godine u okviru koje je uspostavljena saradnja između međunarodnih finansijskih institucija, EBRD, EIB, Evropske komisije, IMF i Svetske banke, nadzornih institucija u zemljama gde posluju evropske banke majke i evropskih zemalja gde posluju banke ćerke, kao i većih evropskih banaka.

Bečka inicijativa se sastojala iz dva dela. U prvom, Koordinaciona inicijativa Evropske banke obezbeđuje privatnom sektoru programe pomoći od strane MMF-a i EU za pet država: BIH, Mađarska, Rumunija, Letonija i Srbija. Ove države imaju značajni deo duga koji dospeva i suočene su sa problemom spoljnog zaduživanja. Deo ovog duga odnosio se na dug prema multinacionalnim bankama i MMF i EU su u cilju prevazilaženja problema vraćanja duga bankama napravile stabilizacioni program za ove zemlje. Ovaj deo uključivao je i Full Forum Meetings, kao osnovu za diskusije sa predstavncima vlasti iz regiona i partnerima iz Zapadne Evrope i MMF-a.

Drugi deo Bečke inicijative bio je objavljen februara 2009. godine, kada su EBRD, EIB i Svetska banka objavili "Zajednički Akcioni plan međunarodnih finansijskih institucija radi podrške bankarskim sistemima i kreditinoj aktivnosti u zemljama Centralne i Istočne Evrope", sa ciljem da se pruži podrška bankarskim sistemima i kreditnoj aktivnosti u privredama Centralne i Istočne Evrope ". Tokom 2009. godine ove institucije su imale sastanak sa 17 bankarskih grupa koje obuhvataju $60 \%$ bankarske aktive $\mathrm{u}$ regionu, posle čega je urađena procena dodatnih potrebnih sredstava tako da su bankama $\mathrm{u}$ regionu odobrena sredstva u visini od 24,5 milijardi evra.

Interakcija između matičnih banaka koje su potpisale Bečku inicijativu i krize 2008. godine ukazuje da u godinama pre nego što je usvojena Bečka inicijativa nije bilo značajnih razlika između rasta kreditne aktivnosti banaka 
in the United States occurred. Specifically, as a result of the loss of confidence in the financial markets, multinational banks significantly reduced their operations in the countries of the Western Balkans.

In the financially integrated world economy, negative trends are spreading in various ways, first of all through cross-border lending, then through the lending activity of subsidiary banks and finally through the lending activity of domestic banks, which, in turn, borrow on the international financial market.

Generally speaking, foreign banks are more tied to their clients' operations in their home countries due to the issuance of long-term loans. This provides a partial explanation of why these banks responded more effectively to the crisis. Other authors (Berglöf, Kaufhold, 2013, pp. 27) point out that the greater participation of foreign banks in the Western Balkan countries is closely linked to a smaller reduction in cross-border lending. Also, the level of production declined less in the countries of the Western Balkans in which the foreign banks are significantly more present, indicating that the presence of foreign banks in the Western Balkan countries has an effect on mitigating the consequences of the financial crisis on these countries, and increases financial stability.

There are different opinions regarding the influence of the crisis on foreign banks' business operations in the Western Balkan countries. One of them is that the lending activity of foreign banks in these countries does not decrease during the crisis, the loans instead experiencing a growth in such circumstances (Goldberg, originally Allen F. et al, 2017). The explanation for this is reflected in the fact that foreign banks are less reliant on the collection of deposits in those countries, being more oriented towards the foreign sources to fund their business operations. Therefore, their loan offer is less pro-cyclical. Also, foreign banks have different clients compared to domestic banks. Other authors (De Haas and Lelyveld, originally Allen F. et al, 2017, p. 495) are stressing the opposite point of view, namely that the European parent banks were not significant sources of additional resources to their subsidiary banks in the Western Balkan countries during the crisis. They also point out that the decrease in the lending activity of the daughter banks was three times higher than the decrease in the credit activity of domestic banks during the 2008-2009 crisis. Unlike the aforementioned statements, some authors (Dages, originally Allen F., et al, 2017) indicate that in the countries of the Western Balkans domestic and foreign banks with a small share of non-performing loans behave similarly, which suggests that the bank's performance or its financial situation, and not ownership, is the key factor in the operations of banks in the aforementioned countries.

At the end of 2008 there was some concern about the banking systems of the European countries undergoing transition, which also included the countries of the Western Balkans. The increased lending activity of the banks in the region before the crisis had an effect on the excessive indebtedness of many private companies in the Western Balkan countries. The reduced funding of subsidiaries by their parent banks not only affected the lending activity of subsidiary banks, but also led to a powerful macroeconomic destabilization. In November of the same year, major European banks proposed to the European Commission, the EBRD and the EIB to undertake a coordinated action in relation to the problems facing the countries of the Western Balkans, and to provide a sufficient level of resources for the banks operating in the region. To this end, the Vienna Initiative was launched in 2008, within which the cooperation was established between the international financial institutions, the EBRD, the EIB, the European Commission, the IMF and the World Bank, supervisory institutions in the parent banks' countries and the European countries in which their subsidiaries operate, as well as the major European banks.

The Vienna Initiative consisted of two parts. In the first part, the European Banking Coordination Initiative provides the private sector with assistance programs by the IMF and the EU for five countries: Bosnia and Herzegovina, Hungary, Romania, Latvia and Serbia. These countries have a significant share of debt that is due and are facing the problem of external borrowing. Part of this debt was debt to multinational banks, and the IMF and the $\mathrm{EU}$, in order to overcome the problem of debt 
kćeri matičnih banaka koje su potpisale Bečku inicijativu i banaka kćeri matičnih banaka koje nisu potpisale ovu inicijativu. Međutim, posle potpisivanja Bečke incijative, $\mathrm{u}$ proseku, banke kćeri čije su matične banke potpisale Inicijativu, beležile su $15 \%$ brži rast kreditne aktivnosti u poređenju sa bankama kćerima čije matične banke nisu potpisale navedenu Inicijativu (Haas i saradnici, 2015, str. 337).

\section{Uticaj novog načina nadzora poslovanja evropskih banaka na kontrolu bankarskih sistema zemalja Zapadnog Balkana}

Osnivanje Evropske monetarne unije 1999. godine bilo je značajno podstaknuto prekograničnom aktivnošću banaka, što je uticalo na potrebu harmonizacije reguisanja banaka i nadzora nad poslovanjem sa ciljem da se izbegne regulaciona arbitraža. Pre krize iz 2007-2008. godine, harmonizacija u pogledu regulisanja poslovanja banaka bila je sprovođena u obliku direktiva, omogućavajući značajnu fleksibilnost nacionalnim nadzornim institucijama da odstupaju u odnosu na prihvaćene evropske standarde. Saradnja između bankarskih nadzornih institucija bila je do krize na dobrovoljnoj osnovi. Izvešaj De Larosijea iz 2009. godine ukazao je da je nedosledna primena propisa glavni problem u Evropskoj uniji u domenu prudencionog regulisanja poslovanja banaka.

Nastanak sistemskog rizika i problemi u sprovođenju tržišne discipline 2008. godine uticali su na nastanak novog pristupa regulisanju poslovanja banaka koji vodi ka jačem i strožem nadzoru banaka. Sporazum Bazel III usredsređuje se na jačanje prudencionog nadzora nad poslovanjem banaka, zahtevajući od banaka veći iznos i bolji kvalitet kapitala banaka kao i bolju sposobnost pokrivanja gubitaka od strane velikih globalnih banaka. Takođe, nadzorne institucije su u cilju bolje primene ovog sporazuma uspostavile složenu nadzornu infrastrukturu, zasnovanu na brojnim novim institucijama kako bi se bolje definisali ciljevi njihovih nadležnosti.

Imajući u vidu činjenicu da su većina banaka koje posluju u zemljama Zapadnog Balkana banke kćeri velikih evropskih banaka, u daljem tekstu ćemo ukazati na primenu Jedinstvenog mehanizma supervizije (Single Supervisory Mechanism), koji se primenjuje u odnosu na 120 najvećih evropskih banaka, a time indirektno i na njihove banke kćeri u zemljama Zapadnog Balkana.

Jedinstveni mehanizam supervizije prvi je korak ka uspostavljanju Evropske bankarske unije, koji je počeo da funkcioniše novembra 2014. godine. Glavni ciljevi ovog sistema jesu da osigura sigurnost i pouzdanost evropskog bankarskog sistema, poveća finansijsku integracijuistabilnostkaoidaosigurausaglašenu superviziju banaka. Evropska centralna banka, kao nezavisna institucija Evropske unije, koja sprovodi navedenu superviziju, ima zadatak da utvrđuje jedinstveni pristup supervizije banaka, harmonizuju načine supervizije banaka i korektivne mere koje se donose $\mathrm{u}$ odnosu na te banke i obezbeđuje jedistvenu primenu politika regulisanja i supervizije banaka. Da bi navedene ciljeve ostvarila, ona vrši neposrednu kontrolu 120 najvećih banaka u Evropskoj uniji (koje učestvuju sa $82 \%$ u ukupnoj aktivi banaka Evropske unije), daje i oduzima ovlašćenja za poslovanje banaka, procenjuje opravdanost preuzimanja druge banke od strane navedenih banaka u okviru Unije, osigurava da je poslovanje banaka u skladu sa prudencionim propisima Evropske unije i može da od pojedine banke zahteva da raspolaže većim kapitalom u odnosu na propisani u slučaju da je suočena sa većim rizicima u svom poslovanju (Schoenmaker, Veron, 2016, str. 3).

Ovako uspostavljena evropska bankarska supervizija pokazala se kao efikasna. Supervizija banaka koje posluju u više zemalja evrozone i u zemljama Zapadnog Balkana sprovođena je zajedničkim kontrolama nadzornih institucija iz više zemalja u kojima posluje određena banka za razliku od prethodne prakse kontrole gde je nadzorna institucija kontrolisala samo banku koja posluje u toj zemlji, bez uvida $\mathrm{u}$ poslovanje njene banke majke ili banke kćeri. Novi način kontrole sprovodili su zajednički supervizorski timovi (Joint Supervisory Teams), koji su za svaku kontrolisanu bankarsku grupu dobijali informacije od Evropske centralne banke i nadležnih supervizorskih institucija iz zemalja gde banka posluje. 
repayment, made a stabilization program for these countries. This part also included "Full Forum Meetings", a basis for discussions with the representatives of the authorities from the region and partners from Western Europe and the IMF.

The second part of the Vienna Initiative was revealed in February 2009, when the EBRD, the EIB and the World Bank announced the "Joint Action Plan for International Financial Institutions to Support Banking Systems and Credit Activity in Central and Eastern European Countries", with the aim of providing support to banking systems and credit activity in the economies of Central and Eastern Europe. During 2009, these institutions had a meeting with 17 banking groups that accounted for $60 \%$ of the banking assets in the region, after which an assessment was made regarding the additional funds needed, and the banks in the region were granted funds in the amount of 24.5 billion euros.

The interaction between the parent banks that signed the Vienna Initiative and the 2008 crisis indicate that in the years before the Vienna Initiative was adopted, there were no significant differences between the growth of lending activity of subsidiaries of parent banks that signed the Vienna Initiative and subsidiaries of parent banks that did not sign this initiative. However, after the signing of the Vienna Initiative, on average, the subsidiaries whose parent banks signed the Initiative recorded a $15 \%$ faster growth in lending compared to subsidiaries whose parent banks did not sign the Initiative (Haas et al, 2015, p. 337).

\section{Influence of the New Method of Operational Supervision of European Banks on the Supervision of the Banking Systems in the Western Balkan Countries}

The foundation of the European Monetary Union in 1999 was significantly prompted by the cross-border activity of banks, which affected the need for harmonization of bank regulation and supervision of operations, in order to avoid regulatory arbitrage. Prior to the 2007-2008 crisis, harmonization with regard to the regulation of banks' operations was carried out in the form of the Directive, allowing significant flexibility for the national supervisory institutions to deviate from the accepted European standards. Cooperation between banking supervisory institutions was on a voluntary basis until the crisis. De Larosière's 2009 report pointed out that inconsistent implementation of regulations is a major problem in the European Union in the domain of prudential regulation of the banks' operations.

The emergence of systemic risk and the problems in implementing the market discipline in 2008 influenced the emergence of a new approach to the banking operations regulation, which strengthened and made the supervision of banks stricter. The Basel III Accord focuses on strengthening prudential supervision of the banks' operations, requiring banks to have higher amounts of better quality capital, as well as improved abilities to cover losses by large global banks. In addition, in order to better implement this agreement, supervisory institutions have set up a complex monitoring infrastructure based on a number of new institutions in order to better define the objectives of their competencies.

Bearing in mind the fact that most banks operating in the countries of the Western Balkans are subsidiaries of large European banks, we will elaborate further on the implementation of the Single Supervisory Mechanism, which applies to the 120 largest European banks, and indirectly to their subsidiaries in the Western Balkan countries.

The Single Supervision Mechanism is the first step towards the establishment of the European Banking Union and began functioning in November 2014. The main objectives of this system are to ensure safety and reliability of the European banking system, increase financial integration and stability, and also to ensure the harmonized supervision of banks. The European Central Bank, as an independent institution of the European Union, carrying out the aforementioned supervision, is tasked with establishing a unified approach to the supervision of banks, harmonizing the methods of bank supervision and corrective measures taken in relation to those banks and ensuring the consistent implementation of the policies for regulating and supervising banks. 


\section{Zaključna razmatranja}

U članku je razmatrana problematika transformacije bankarskih sistema zemalja Zapadnog Balkana, načini i posledice ovog procesa na bankarske sisteme navedenih zemalja, kao i nadzor nad poslovanjem ovih banaka. Imajući u vidu da je proces kupovine i pripajanja banaka od strane većih banaka u Zapadnoj Evropi okončan sredinom osamdesetih godina prošlog veka, zapadnoevropske banke su počele da šire svoje poslovanje i kupovinom državnih banaka u evropskim državama u tranziciji, uključujući i zemlje Zapadnog Balkana.

Buduće poslovanje banaka u zemljama Zapadnog Balkana još uvek je delom pod uticajem finansijske krize iz 2007-2008. godine. Kriza i njene posledice ukazale su na ranjivost banaka koje posluju u razvijenim evropskim zemljama $u$ pogledu strukture izvora finansiranja kao i stvarnih rizika proizašlih iz poslovanja ovih banaka u zemljama Zapadnog Balkana. Takođe, kriza je ukazala na potrebu drugačijeg regulisanja poslovanja banaka.
Bankarska supervizija posle navedene krize dobija veći značaj imajući u vidu i povećanu međusobnu povezanost finansijskih tržišta evropskih zemalja, njihovih matičnih i banaka kćeri. Ovo podrazumeva usaglašenost poslovanja banaka u zemljama Zapadnog Balkana sa evropskom regulativom u cilju obezbeđenja finansijske stabilnosti. Važan segment adekvatne supervizije banaka $u$ navedenim zemljama jeste saradnja između nacionalnih supervizorskih institucija $i$ Evropske centralne banke kako bi se izbeglo donošenje diskrecionih odluka u odnosu na banke koje posluju u zemljama Zapadnog Balkana. Kao što je pokazala finansijska kriza tokom 2007-2008. godine, potreban je odgovarajući nivo harmonizacije propisa i centralizacije supervizije na nivou Evropske unije u cilju boljeg funkcionisanja bankarskih sistema svih zemalja. Usaglašavanje poslovanja bankarskih sistema država Zapadnog Balkana sa evropskim prudencionim propisima sprovedeno je primenom sporazuma Bazel III. 
In order to achieve these objectives, it directly controls the 120 largest banks in the European Union (which participate with $82 \%$ in the total assets of the European Union banks), grants and revokes the operating licenses of banks, assesses the justification for the takeover of another bank by those banks within the Union, ensures that the operations of banks comply with the prudential regulations of the European Union and may require the individual bank to dispose of a higher capital in proportion to the prescribed in case it faces significant risks in its operations (Schoenmaker, Véron, 2016, p. 3).

Thereby established European banking supervision proved to be effective. The supervision of banks operating in several Eurozone countries and in the Western Balkans is carried out by joint control of supervisory institutions from several countries in which a particular bank operates, unlike the previous control practices, where the supervisory institution controlled only the banks operating in that country, without having any insight into the operations of its parent bank or its subsidiary. The new controlling method was implemented by the Joint Supervisory Teams, which received the relevant information for each controlled banking group from the European Central Bank and competent supervisory institutions from the countries in which the concerned bank operated.

\section{Concluding Considerations}

The paper deals with the issues of the transformation of the banking systems of the Western Balkan countries, modalities and consequences of this process on the banking systems of these countries, as well as the supervision of the operations of these banks. Bearing in mind that bank purchases and mergers by major banks in Western Europe ended in the mid-80s, Western European banks began to expand their business operations, among other ways, by purchasing state-owned banks in European countries undergoing transition, including the countries of the Western Balkans.

The future performance of the banks in the Western Balkan countries is still partly under the influence of the financial crisis of 2007-2008. The crisis and its consequences highlighted the vulnerability of banks operating in developed European countries in terms of the structure of sources of financing, as well as the real risks arising from the operations of these banks in the Western Balkans. Furthermore, it highlighted the need for a different regulation of banking operations.

After the aforementioned crisis, the banking supervision has been gaining in importance, bearing also in mind the increased interconnection of the financial markets of European countries, their parent banks and daughter banks. This implies the compliance of the banks in the Western Balkan countries with the European regulations in order to ensure financial stability. An important segment of adequate bank supervision in these countries is the cooperation between national supervisory institutions and the European Central Bank in order to avoid making discretionary decisions in relation to the banks operating in the countries of the Western Balkans. And, as the financial crisis showed in 2007-2008, an appropriate level of harmonization of regulations and centralization of supervision at the level of the European Union is needed in order for the banking systems of all countries to operate better. The harmonization of the operations of the banking systems of the Western Balkan countries with the European prudential regulations was carried out through the Basel III Accord. 


\section{Literatura / References}

1. Agencija za bankarstvo Federacije Bosne i Hercegovine. Informacija o bankarskom sistemu Federacije $\mathrm{BiH}$ 30.06.2017. godine, preuzeto 26.11.2017. sa sajta http://www.fba.ba/publikacije banke/info_o_bank_sistemu_fbih_30.06.2017.

2. Agencija za bankarstvo Republike Srpske. Izvještaj o stanju u bankarskom sistemu Republike Srpske na dan 30.06.2017. godine, preuzeto 26.11.2017. sa sajta http://www.abs. ba./izvještaji_o_stanju_bankarskog_sistema_ RS_30062017

3. Allen F., Jackowicz K., Kowalewski O., Kozlowski L. Bank Lending, Crises, and Changing Ownership Structure in Central and Eastern European Countries, Journal of Corporate Finance, 42 (2017).

4. Angeloni I. The Single Supervision Mechanism, European Economy, 2015-3, preuzeto 13.12.2017. godine sa sajta: http://www.European-economy. eu

5. Barjaktarević L, Paunović M: Komparativna analiza bankarskog sektora u zemljama centralne i istočne Evrope sa osvrtom na Srbiju, Anali Ekonomskog fakulteta u Subotici, Vol. 48, 2012.

6. Beck T. Regulatory Cooperation on Cross Border Banking - Progress and Challenges After the Crisis, National Institute Economic Review, 2016 preuzeto 13.01.2018. sa sajta http://www.journals. sagepub.com

7. Buch C. M., Opening Up for Foreign Banks: How Central and Eastern Europe Can Benefit, Economics of Transition, Volume 5 (2), 1997.

8. Cavelears P., Haan J., Hilbers P., Stelling B., Challenges for Financial Sector Supervision, DNB Occasional Studies, Vol. 11 No. 6. preuzeto 25.09.2017. sa sajta http://www.dnb.nl/newspublications/dnb-occasional-studies

9. Claessens S., Horen N. Impact of Foreign Banks, DNB Working Paper, No. 370, 2013, preuzeto 25.09.2017. sa sajta: http://www.dnb.nl/en/ publications/dnb_working paper

10. Dinkić M., Jelašić R:, Strategija restrukturiranja bankarskog sistema, Ekonomski anali, Vol. 45. Van. broj, Beograd, 2001.

11. European Investment Bank, EIB, 2013., Banking in Central and Eastern Europe and Turkey - Challenges and Opportunities, preuzeto 26.11.2017. sa sajta: http://eig.org/attachments/ efs/economic_report_banking_cee_turkey.pdf
12. European Central Bank, Banking Supervision. Single Supervision Mechanism, preuzeto 09.11.2017. sa sajta: http://www. bankingsupervision.europe.eu

13. Elliot D. Stantos, A. O. Estimating the Costs of Financial Regulations, IMF Staff Discussion Note, 2011, preuzeto 13.01.2018. sa sajta: http://www. imf.org/en/publications/staffdiscussion:notes/ issue/estimating-the-costs-of-financialregulation-26231

14. Frydman R. et al: When Does Privatization Work? The Impact of Private Ownership on Corporate Performance in the Transition Economies, Quarterly Journal of Economics, Volume CXIV, November 1999.

15. Fungacova Z, Shamsur A. Does Bank Competition Reduce Cost of Credit, Cross Country Evidence from Europe, Bank of Finland, Bofit Discussion Papers, 6/2016, preuzeto 14.04.2017. sa sajta http://www.suomenpanki.fi/en/other-pages

16. IMF: Improved Outlook for Bank Lending in Emerging Europe as Funding Conditions Stabilize and Stocks of Bad Loans Fall, New Vienna Initiative Report Show, Press Release No. 17/159, May 11, 2017.

17. Impravido G., Rudolph H., Ruggerone L., Bank Funding in Central, Eastern and South Eastern Eurupe Post Lehman: a New Normal, IMF Working Paper, preuzeto 25.12.2017. sa sajta http:www.imf.org/publications/wp/issue

18. Haas De R, Korniyenko Y, Loukoianova E, Pivovarsky A: Foreign Banks and the Vienna Initiative: Turning Sinners into Saints? preuzeto 11.08.2018. sa sajta: http:www.imf.org/ publications/wp/issue

19. Haas De R, Korniyenko Y, Pivovarsky A, Tsankova T: Taming the Herd? Foreign Banks, the Vienna Initiative and Crisis Transmission, Journal of Financial Intermediation, Vol. 24. Issue 3, preuzeto 11.08.2018. sa sajta http:www.ScienceDirect.com

20. Hrvatska narodna banka: Bilten o bankama, br. 30, avgust 2017, preuzeto 26.11.2017. sa sajta: http:/www.hnb.hr/analize-i-publikacije/bilten o bankama

21. Kaufhold, J., Multinational banks in Times of Financial Crises: Consequences for Emerging Europe and Cross Border Regulation, Copenhagen Business School, 2013, master teza preuzeta 30.01.2017. sa sajta: http:// www.studenttheses.cbs.dk/bitstream/handle/10417 
22. Kazinczy E., The Transition Times of the Banking System in South-Eastern Europe - From Systematic Collapse to Stabilisation, Corvinus Research, Corvinus University Budapest, 2013, preuzeto 07.07.2017. sa sajta: http://www. convinus.hu/1242/kg_2013n2p151.pdf

23. Matić. V., Finansije srpske, Udruženje banaka Srbije, Beograd, 2014.

24. Miklaszevska E., Nikolajcyk K., Pawlowska M., Do Safe Banks Create Safe Systems, preuzeto 21.3.2017. sa sajta://www.cairn.info

25. Narodna banka Jugoslavije. Bankarski sektor SR Jugoslavije u 2001. godini, preuzeto 26.12.2017. sa sajta: http://www.nbs.rs.bankarski_sektor_01.pdf

26. Narodna banka Makedonije: Izveštaj o rizicima u bankarskom sistemu Republike Makedonije u drugom kvartalu 2017. godine preuzeto sa sajta: http://www.nbrm.mk/content/regulativa/ kvartalen_30_06_2017.pdf

27. Narodna banka Srbije. Bankarski sektor 2002. Preuzeto 26.12.2017. sa sajta: http://www.nbs. rs.bankarski_sektor_02.pdf

28. Narodna banka Srbije: Izveštaj o stanju u bankarskom i ukupnom finansijskom sistemu zemlje za 2003, preuzeto 26.12.2017. sa sajta: http:// www.nbs.rs_bankarski_sektor_03.pdf

29. Narodna banka Srbije: Bankarski sektor u Srbiji, Izveštaj za četvrti kvartal 2004, preuzeto 26.12.2017. sa sajta: http://nbs.rs.kvartalni_ izvestaj_IV_04.pdf

30. Narodna banka Srbije: Bankarski sektor $u$ Srbiji, Izveštaj za četvrti kvartal 2005, preuzeto 26.12.2017. sa sajta: http://nbs.rs.kvartalni_ izvestaj_IV_05.pdf

31. Narodna banka Srbije: Kontrola poslovanja banaka, Izveštaj za četvrti kvartal 2006, preuzeto 26.12.2017. sa sajta: http://nbs.rs.kvartalni_ izvestaj_IV_06.pdf

32. Narodna banka Srbije: Kontrola poslovanja banaka, Izveštaj za četvrti kvartal 2007, preuzeto 26.12.2017. sa sajta: http://nbs.rs.kvartalni_ izvestaj_IV_07.pdf

33. Narodna banka Srbije: Kontrola poslovanja banaka, Izveštaj za četvrti kvartal 2008, preuzeto 26.12.2017. sa sajta: http://nbs.rs.kvartalni_ izvestaj_IV_08.pdf
34. Narodna banka Srbije: Kontrola poslovanja banaka, Izveštaj za četvrti kvartal 2009, preuzeto 26.12.2017. sa sajta: http://nbs.rs.kvartalni_ izvestaj_IV_09.pdf

35. Narodna banka Srbije: Kontrola poslovanja banaka, Izveštaj za četvrti kvartal 2010, preuzeto 26.12.2017. sa sajta: http://nbs.rs.kvartalni_ izvestaj_IV_10.pdf

36. Narodna banka Srbije: Kontrola poslovanja banaka, Izveštaj za četvrti kvartal 2011, preuzeto 26.12.2017. sa sajta: http://nbs.rs.kvartalni_ izvestaj_IV_11.pdf

37. Narodna banka Srbije: Kontrola poslovanja banaka, Izveštaj za četvrti kvartal 2012, preuzeto 26.12.2017. sa sajta: http://nbs.rs.kvartalni_ izvestaj_IV_12.pdf

38. Narodna banka Srbije: Kontrola poslovanja banaka, Izveštaj za četvrti kvartal 2013, preuzeto 26.12.2017. sa sajta: http://nbs.rs.kvartalni_ izvestaj_IV_13.pdf

39. Narodna banka Srbije: Kontrola poslovanja banaka, Izveštaj za četvrti kvartal 2014, preuzeto 26.12.2017. sa sajta: http://nbs.rs.kvartalni_ izvestaj_IV_14.pdf

40. Narodna banka Srbije: Kontrola poslovanja banaka, Izveštaj za četvrti kvartal 2015, preuzeto 26.12.217. sa sajta: http://nbs.rs.kvartalni_ izvestaj_IV_15.pdf

41. Narodna banka Srbije: Kontrola poslovanja banaka, Izveštaj za četvrti kvartal 2016, preuzeto 26.12.2017. sa sajta: http://nbs.rs.kvartalni_ izvestaj_IV_16.pdf

42. Narodna banka Srbije: Kontrola poslovanja banaka, Izveštaj za drugi kvartal 2017, preuzeto 26.12.2017. sa sajta: http://nbs.rs.kvartalni_ izvestaj_II_17.pdf

43. Ruziev R., Dow S.C., A Review of Banking Sector Reforms in Transition Economies, Centre for Global Finance, University of the West of England, 2013, preuzeto 07.07.2017. sa sajta: http:www. uwe_ac.uk/faculties/bbc/documents/03-13.pdf

44. Schoemaker D., Veron N., European Banking Supervision: Compelling Start, Lingering Challenges, 2016., preuzeto 09.11.2017. sa sajta: http://www.voxeu.org/article/early-assesmentsingle-supervisory-mechanism 